\title{
BLIŹNIAKI ZROŚNIĘTE I CIĄŻE MNOGIE NA ŻUŁAWACH. PRZYCZYNEK DO BADAŃ NAD DZIEJAMI TOKOLOGII W XVI-XIX WIEKU
}

Streszczenie. Bliźniaki nierozdzielone oraz ciąże mnogie to temat który jak dotąd nie doczekał się szerszego opracowania. Tekst stanowi zaledwie drobny przyczynek, gdzie w oparciu o księgi metrykalne, leksykony oraz prasę próbuje się odnaleźć przypadki nietypowych narodzin. Z pewnością przytoczone w tekście dane są niepełne i wymagają uzupełnienia o kolejne źródła. Zupełnie wyjątkowy wydaje się Autorom odnotowany w księgach metrykalnych dla roku 1780 przypadek narodzin pięcioraczków we wsi Lubieszewo. Czy jest to pierwszy dotychczas odnotowany przypadek pięcioraczków na ziemiach polskich? Bez dokładniejszych badań nad tym zagadnieniem nie poznamy odpowiedzi na tak postawione pytanie.

Słowa kluczowe: Żuławy, demografia, położnictwo, dziecko, rodzina, księgi metrykalne.

$\mathrm{P}$

rezentowany tekst stanowi zaledwie przyczynek do tematu niepodejmowanego dotychczas szerzej przez badaczy zajmujących się demografią historyczną. Chodzi o zjawisko odnotowywanych na łamach prasy oraz w księgach metrykalnych informacji dotyczących nietypowych porodów. Poprzez nietypowe porody rozumiemy takie narodziny, w wyniku których na świat przychodzi zdeformowana istota lub takie narodziny, gdzie w wyniku ciąży mnogiej mamy do czynienia z narodzinami wieloraczków. W przypadku tych ostatnich, o ile ciąże bliźniacze, czy nawet trojacze, nie były i nie są czymś nad wyraz wyjątkowym, o tyle narodziny czworaczków, czy tym bardziej pięcioraczków, należały i należą do sytuacji nadzwyczajnych. 
Zatem daje się skonstatować, iż zarówno narodziny zdeformowanych dzieci, jak również wieloraczków stanowiły oraz do dziś stanowią wyłom w normalnej i codziennej praktyce położniczej.

W niniejszym tekście skupiamy się przede wszystkim na obszarze Żuław. Jednakże poza terenem Delty Wisły często odwołujemy się również do obszaru Gdańska, który jak narazie jest ośrodkiem najlepiej przebadanym pod kątem analizowanego przez nas zagadnienia, a jednocześnie ze względu na bliskie położenie względem obszaru Żuław stanowi ośrodek o zbliżonej specyfice i etnosie. Niekiedy w celu ukazania charakteryzowanych zjawisk na szerszym tle odwołujemy się do statystyk zbiorczych (np. w przypadku XIX wieku do statystyk prowadzonych dla rejencji gdańskiej, w skład której wchodził wówczas teren Żuław). Ramy chronologiczne pracy ze względu na specyfikę zagadnienia są tu bardzo płynne. Trudno bowiem zamknąć w określonych cezurach czasowych zagadnienia nietypowych porodów, które przecież są zjawiskiem, które występuje po dziś dzień. Zasadniczo jednak najwięcej uwagi w tekście poświęcamy okresowi wczesno-nowożytnemu oraz nowożytnemu, tj. czasom XVI-XIX wieku. Jeden przypadek z okresu XX wieku przytaczamy wyłącznie po to, aby ukazać, jak wyjątkowe były narodziny wieloraczków nawet w tym okresie, w którym przecież istniały już antybiotyki, hormony oraz stosowało się środki chemiczne mogące wpłynąć w jakiś sposób na wystąpienie ciąży mnogiej bądź na narodziny zdeformowanego płodu.

Celem artykułu jest zatem zasygnalizowanie problematyki, która jak dotąd nie doczekała się w polskiej historiografii szerszych studiów analitycznych. Liczymy, że ten tekst zwróci uwagę na zaniedbany jak dotąd problem badawczy, stanowiąc jednocześnie przyczynek do dziejów tokologii na terenie Rzeczpospolitej.

Bliźnięta nierozdzielane określane często jako bliźnięta syjamskie rodzą się niezmiernie rzadko. Szacuje się, że tego typu wada występuje raz na 50, a nawet 100 tysięcy żywych urodzeń, z czego zazwyczaj 40-60\% takich bliźniaków rodzi się martwych, a w około $35 \%$ przypadków ich przeżycie nie przekracza doby ${ }^{1}$. W przeszłości nierozdzielone bliźniaki uważano, tak jak i inne dzieci urodzone z poważnymi wadami - takimi jak choćby wodogłowie - za monstra. Wzmianki o nich pojawiają się w wielu dziełach anatomicznych z okresu nowożytnego. Samo słowo wywodzi się z języka łacińskiego, gdzie wyraz monstrare oznacza pokazywać". Nie powinno zatem dziwić, że zmarłe potworki" preparowano, a następnie wystawiano na widok publiczny w cieszących się wówczas popularnością kunstkamerach, panoptikach, czy po

${ }^{1}$ R.P. Mathew, S. Francis, R.S. Basti, H.B. Suresh, A. Rajarathnam, P.D. Cunha, S.V. Rao, Bliźnięta nierozdzielone - rola badań obrazowych oraz nowe technologie, b.m.w. 2017, s. 259. 
prostu gabinetach osobliwości. Fala mody na tego typu przybytki nasiliła się szczególnie w okresie renesansu i baroku, kiedy to uwagę ludzką przyciągały wszelkie fenomeny przyrody, jej dziwactwa i anomalia ${ }^{2}$. Jak charakteryzuje to K. Pomian:

Niczym nie pohamowana w okresie XVI-XVIII wieku ciekawość kieruje się spontanicznie ku temu, co najrzadsze, najtrudniej dostępne, najbardziej zadziwiające, najbardziej zagadkowe. U wielu kolekcjonerów tych czasów, tendencja ta osiąga szczyt w zainteresowaniu mumiami, hieroglifami, wszystkimi rzeczami podejrzewanymi o znaczenia tajemne: pierścieniami, niektórymi gemmami, amuletami ${ }^{3}$.

Do dziś w licznych muzeach na całym świecie znajdują się okazy sprzed wieków, a wśród nich również tego typu osobliwości

Jedną z najsłynniejszych w XVII wieku Kunstkamer, była ta mieszcząca się na obrzeżach Amsterdamu i należąca do Frederika Ruyscha, który stworzył przewodnik po tym gabinecie osobliwości. Jeden z egzemplarzy ów przewodnika zatytułowany Thesaurus Anatomicus zachował się w zbiorach Biblioteki Elbląskiej po dziś dzieńn . Z pewnością owe gabinety osobliwości cieszyły się wielką popularnością wśród studentów medycyny peregrynujących w tym czasie po Europie w celu zdobycia lub zgłębienia swej wiedzy. Jak wskazuje L. Kooijmans:

Od studenta medycyny oczekiwano, że za granicą nie będzie tylko uczęszczał na wykłady, ale także odwiedzi szpitale, aby zobaczyć jak się tam pracuje. Ponadto powinien zwiedzać publiczne i prywatne zbiory naturaliów, zwracając szczególną uwagę na egzotyczne rośliny i minerały, które mogą być przydatne do warzenia lekarstw ${ }^{6}$.

2 B. Fabiani, Niziołki, łokietki, karlikowie, Warszawa 1980, s. 30. Dla okresu średniowiecza, choć wzmianki tego typu odnotowywano w różnego rodzaju relacjach, co świadczy poniekąd o pewnej fascynacji tematem, jednakże nie mamy tu do czynienia jeszcze z kolekcjonerstwem na większą skalę. Zob.: M.H. Malewicz, Zjawiska przyrodnicze w relacjach dziejopisarzy polskiego średniowiecza, Wrocław 1980, s. 67-77.

${ }^{3}$ K. Pomian, Zbieracze i osobliwości. Paryż - Wenecja XVI-XVIII wiek, tłum. A. Pieńkos, Lublin 2001, s. 109.

${ }^{4}$ Tego typu słynne muzeum znajduje się na przykład w Petersburgu (Kunstkamera), czy też Berlińskim Muzeum Historii Medycyny Charité. Znacznie uboższą kolekcje możemy również obejrzeć w szpitalu św. Ducha - oddziale Muzeum Mikołaja Kopernika we Fromborku.

${ }^{5}$ F. Ruysch, Frederici Ruyschii, anatomiae et botanices professoris thesaurus anatomicus primus [-decimus] cum figurisaeneis = Het eerste [-zynde] anatomisch Cabinet van Frederic Ruysch, professor van de Anatomiae en Botan met kopere Platen, Amsterdam 1701-1716.

${ }^{6}$ L. Kooijmans, Niebezpieczna wiedza. Wizje i lęki w czasach Jana Swammerdama, tłum. R. Pucek, Warszawa 2010, s. 15. 
Zbieranie osobliwości, nie ominęło nawet królów polskich. Między innymi kiedy słynny chirurg Daniel Schwabe 9 lipca 1635 roku w Królewcu usunął operacyjnie nóż z żołądka pewnego młodego wieśniaka (człowiek ów przeżył). Ten zabieg na tyle wzbudził zainteresowanie u króla Władysława IV, że nabył wyciągnięty z żołądka nóż i włączył go do swojej kolekcji ${ }^{7}$. Po jego śmierci ów nóż trafił w ręce Jana Kazimierza, który przekazał go z kolei Bogusławowi Radziwiłłowi, a ten testamentem darował go uniwersytetowi w Królewcu ${ }^{8}$.

Karty średniowiecznych i wczesno-nowożytnych relacji zapełniają opisy, rzekomo niezwykłych porodów, których efektem były hybrydy. Informacje o wyjątkowych" narodzinach odnotowywano w domowych archiwach, kronikach, drukach ulotnych, traktatach medycznych, kalendarzach, a nawet prasie $^{9}$. Przyjście na świat dziwnej istoty, takiej jak niemowlę o dwóch głowach, czyniło wyrwę w porządku życia, łamało utrzymujące się normy, wzbudzało strach, oszołomienie, ale i ciekawośćc ${ }^{10}$. Zatem nic dziwnego, że tego typu sytuacje uznawano za znaki zwiastujące wojny, głód i epidemie, bądź przypisywano je czarom, a kobiety rodzące monstra uznawano za czarownice, twierdząc, że poczęcie jest efektem kontaktów cielesnych kobiety $\mathrm{z}$ diabłem ${ }^{11}$.

Lekarze podejmowali próby wyjaśnienia wad noworodków, uciekając się w tym celu do przeprowadzania sekcji zwłok. Jednym z najsłynniejszych gdańskich profesorów medycyny, który jako pierwszy w Europie środkowej podjął się przeprowadzenia publicznej sekcji zwłok noworodka z wadami mnogimi, był Joachim Oelhaf ${ }^{12}$. Przypadek, który skłonił go do przeprowa-

7 S. Sokół, Medycyna w Gdańsku w dobie odrodzenia, Wrocław-Warszawa 1960, s. 109.

8 Tamże; tenże, Eustachy Holwell leczył jednorożcem, (Kartka z dziejów gdańskiej medycyny XVII w.), „Rocznik Gdański” 1955, t. XIV, s. 182, przyp. 10; J. Serczyk błędnie wskazuje, jakoby w tym samym roku operacji usunięcia noża z brzucha parobka Andreasa Grunheide miał się podjąć profesor Wydziału Medycznego uniwersytetu w Królewcu Georg Lothus, ten jedynie jako doktor medycyny wraz z dwoma innymi tytularnymi medykami doglądał przeprowadzanego zabiegu, co było wówczas praktyką zwyczajową. Zob.: J. Serczyk, Albertyna. Uniwersytet w Królewcu (1544-1945), Olsztyn 1994, s. 45.

${ }^{9}$ Zob. A. Kucharski, Theatrumperegrinandi. Poznawcze aspekty staropolskich podróży w epoce późnego baroku, Toruń 2013, s. 412-413.

10 A. Wieczorkiewicz, Monstruarium, Gdańsk 2019, s. 11.

${ }^{11}$ J. Wijaczka, Procesy o czary w Prusach Książęcych (Brandenburskich) w XVI-XVIII wieku, Olsztyn 2019, s. 56.

12 Więcej na temat J. Oelhafa zob.: F. Schwarz, Ärzte im 16. - 18. Jahrhundert, „Danziger Familiengesichtliche Beiträge” 1939 H. 4, s. 33; J. Kaufmann, Über Danziga Sanitats - und Medizinalwesenim 16. und 17. Jhr., „Mitteilungen des Westpreussischen Gesichtsverein” 1904, H. 1-2, s. 11-12; J.H. Kämpfert, Danziger Naturwissenschaftler. Ein Überblick vom ausgehenden Mittelalter bis zum 19. Jahrhundert, [w:] Danzig in acht Jahrhunderten. Beiträge zur Geschichte eines hansischen und preußischen Mittelpunktes. Quellen und Darstellungen zur Geschichte West- 
dzenia pokazowego zabiegu miał miejsce 27 lutego 1613 roku w położonej niedaleko Gdańska wsi Pruszcz (obecnie Pruszcz Gdański), gdzie żona szewca Bartholomaeusa Kropa - Anna, która powiła troje dzieci, tj. dwie dziewczynki i jedno monsturum o niezidentyfikowanej płci ${ }^{13}$. Innym wybitnym gdańskim lekarzem przeprowadzającym sekcję zwłok bliźniaków nierozdzielonych był Johann Adam Kulmus ${ }^{14}$. Sekcja miała miejsce 18 lutego 1724 roku w gdańskim Ateneum w tamtejszej sali anatomicznej. Obiektem jego zainteresowania stały się dwie zrośnięte dziewczynki urodzone w lutym w dzielnicy Nowe Szkoty (ich rodzicami byli Marianna i Andrzej Czepanski) ${ }^{15}$. Kulmus w protokole $\mathrm{z}$ wykonanej sekcji poza dokładnym omówieniem jej przebiegu zastanawiał się nad genezą powstania zroślaków, jak również nad tym czy owo „monstrum” należy uznać za człowieka, a jeżeli tak, to czy traktować je jako jedną czy dwie osoby. Jednak ostatecznie doszedł do wniosku, że gdyby sekcjonowane przez niego zrośnięte dziewczynki przeżyły, to należałoby je uznać za dwie odrębne osoby z dwiema duszami ${ }^{16}$. Kwestia określenia tego, czy zroślaki należy traktować jako dwa odrębne byty czy jako jeden, miała istotne znaczenie, bowiem określała kwestie chrztu, który w razie potraktowania zroślaków jako istot odrębnych - o dwóch duszach - wymagał chrztu podwójnego.

Z pewnością przypadki narodzin bliźniaków nierozdzielonych, choć rzadkie, zdarzały się również na Żuławach, o czym świadczy przypadek odnotowany na łamach elbląskiego czasopisma Königlich Genehmigte

preußen, Bd. 23, hrsg. von Bernhart Jähnig, Peter Letkemann, Münster 1985, s. 199; tenże, Aspekte der Medizingeschichte in Danzig im Rahmen der Naturforschenden Gesellschaft, [w:] Deutsch-polnische Begegnung zu Wissenschaft und Kultur Schriftenreihe der Danziger Naturforschenden Gesellschaft, Bd. 2, hrsg. Gornig H. Gilbert, Lübeck 1998, s. 39-40; M. Bogucka, Illness and Death in a Maritime City. Gdańsk in the Seventeenth Century, [w:] Człowiek i świat. Studia z dziejów kultury i mentalności XV-XVIII w., Warszawa 2008, s. 398, 408-409; taż, Health care and poor relief in Danzig (Gdansk). The sixteenth- and first half of the seventeenth century, [w:] Health Care and Poor Relief in Protestant Europe 1500-1700, ed. 0.P. Grell and A. Cunningham, London 1997, s. 214; S. Sokół, dz. cyt., s. 75-89; A. Szarszewski, Joachim Oelhaf (1570-1630), [w:] Joachim Oelhaf I jego następcy, red. A. Szarszewski, B. Siek, Gdańsk 2013, s. 32-35; B. Siek, A. Szarszewski, Vita medicorum Gedanensium Ludwika von Hammena i Valentina Schiieffa, Gdańsk 2015, s. 61.

${ }^{13}$ S. Konieczna, dz. cyt., s. 43-49.

14 Więcej na temat A. Kulmusa zob.: S. Sokół, Historia gdańskiego cechu chirurgów 14541820, Wrocław-Warszawa 1957, s. 45; tenże, Medycyna w Gdańsku w dobie odrodzenia..., s. 67, 83, 98; F. Schwarz, Ärzte im 16.-18. Jahrhundert, „Danziger Familiengesichtliche Beiträge” 1941, H. 6, s. 21; J.H. Kämpfert, Danziger Naturwissenschaftler..., s. 192; tenże, Aspekte der Medizingeschichte in Danzig..., s. 38; K. Kubik, L. Mokrzecki, Trzy wieki nauki gdańskiej. Szkice z dziejów od XVI do XVIII wieku, Wrocław 1976, s. 151-152.

${ }^{15}$ E. Iżycka-Świeszewska, B. Hermann, J. Gulczyński, dz. cyt., s. 87.

16 Tamże, s. 88. 
West-Preußische Elbingische Zeitung von Staats- und Gelehrten Sachen". Odnotowany tam feralny poród miał miejsce 11 maja 1811 roku w miejscowości Neuteichwalde (Stawiec) ${ }^{17}$. Notka zawiadamiająca o owym porodzie była niezwykle lakoniczna i nie podawała personaliów matki. Brzmiała następująco:

Na szczególną uwagę zasługują dziwne z biologicznego punktu widzenia narodziny, które miały miejsce 11 dnia tego miesiąca [maja - R.K.] o godzinie 3 po południu. Żona pracownika dniówkowego (Tagelöhner) z tutejszej wsi (Neuteichwalde) urodziła dwoje zrośniętych ze sobą dzieci płci żeńskiej. Dziecko, którego głowa jako pierwsza opuściła łono matki miało schowaną prawą rękę pod lewą ręką drugiego dziecka i jego brzuchem. Natomiast lewa ręka drugiego dziecka obejmowała szyje pierwszego dziecka. Dwie pozostałe ręce dzieci leżały skrzyżowane na sobie. Dziewczynki miały wspólną pępowinę i były ze sobą zrośnięte podbrzuszem, wątrobą, klatką piersiową aż po szyję. Dzieci przyszły na świat martwe, a ich matka już dwa dni przed rozwiązaniem nie czuła żadnej aktywności w jej łonie. Życiu matki nie zagraża żadne niebezpieczeństwo ${ }^{18}$.

Już w XIX wieku próbowano typologizować rodzaje bliźniąt nierozdzielonych. Odnosząc się do dzisiejszych klasyfikacji, na podstawie powyższego opisu należy przyjąć, że urodzone w okolicy Nowego Stawu bliźniaczki należy klasyfikować jako thoracopagus, czyli taki rodzaj zrośnięcia, w którym bliźnięta zwrócone są do siebie twarzami i zrośnięte od górnej części klatki piersiowej do górnej części jamy brzusznej ${ }^{19}$.

Poza monstrami, niezwykłymi wydarzeniami wzbudzającymi z pewnością wśród mieszkańców Żuław i nie tylko Żuław sensację, były ciąże mnogie. Jeden z najwybitniejszych znawców demografii okresu nowożytnego (XVIXIX w.) Jan Baszanowski, powołując się na ustalenia Michaela Christiana Hanowa zawarte w gdańskim periodyku Danziger Erfahrungen"20, wskazywał, że na 7560 urodzeń mających miejsce w Gdańsku w latach 1739-1742 odnotowano zaledwie 76 przypadków (1\%) bliźniaków ${ }^{21}$. Wzmiankował również, że w statystykach nie odnotowywano trojaczków czy czworaczków.

17 Wieś położona w okolicach Nowego Stawu (Neuteich).

${ }_{18}$ Königlich genehmigte West-Preußische Elbingsche Zeitung von Staats- und gelehrten Sachen, 1811, nr. 41, s. 4.

19 R.P. Mathew, S. Francis, R.S. Basti, H.B. Suresh, A. Rajarathnam, P.D. Cunha, S.V. Rao, dz. cyt., s. 263.

${ }^{20}$ Więcej na temat tego czasopisma zob. J. Paluchowski, Danziger Erfahrungen $w$ latach 1739-1793. Studium z dziejów gdańskiego czasopiśmiennictwa, Warszawa 2013.

${ }^{21}$ J. Baszanowski, Przemiany demograficzne w Gdańsku w latach 1601-1846, Gdańsk 1995, s. 235. 
Dodał także, że nie ma w tym nic dziwnego, ponieważ porody pierwszych zdarzają się średnio raz na dziesięć tysięcy, a drugich na ponad trzysta tysięcy urodzeń ${ }^{22}$. Jak wykazał E. Kizik, dane na których opierał się J. Baszanowski, wymagają zestawienia z księgami metrykalnymi, które są prymarnym źródłem wobec zbiorczych materiałów statystycznych. Odnotowuje się w nich również narodziny wieloraczków ${ }^{23}$. Analiza takich ksiąg za lata 1814-1874 dla parafii ewangelickiej w Drewnicy, w której skład wchodziły miejscowości takie jak: Drewnica (Schönbaum), Drewniczka (Schönbauerweide), Leszkówki (Letzkauerweide), Gdańska Głowa (Danziger Haupt) ${ }^{24}$, Przemysław (Prinzlaff) i Izbiska (Freienhuben) pozwoliła odnotować w sumie 4690 porodów, z czego 80 porodów (niecałe 2\%) to porody bliźniaków (Tabela 1). Natomiast nie odnotowano narodzin żadnych trojaczków ani czworaczków. Uzyskane wartości choć nie dotyczą stricte terenów Żuław, a pobliskiej Mierzei ${ }^{25}$, można bez przeszkód traktować jako egzemplifikację dla ewangelickich parafii żuławskich.

\section{Tabela 1}

Liczba bliźniaków w stosunku do ogólnej liczby urodzeń w parafii ewangelickiej w Drewnicy

\begin{tabular}{|c|c|c|}
\hline Rok & $\begin{array}{c}\text { Ogólna liczba } \\
\text { urodzeń }\end{array}$ & Bliźniaki \\
\hline 1814 & 82 & 1 \\
\hline 1815 & 85 & 1 \\
\hline 1816 & 76 & 2 \\
\hline 1817 & 79 & 1 \\
\hline 1818 & 84 & 1 \\
\hline 1819 & 82 & 1 \\
\hline 1820 & 97 & 0 \\
\hline 1821 & 80 & \\
\hline
\end{tabular}

22 Tamże, s. 235-236.

${ }^{23}$ E. Kizik, Uwagi o ruchu naturalnym $w$ parafii NMP $w$ Gdańsku $w$ drugiej połowie XVII i w XVIII wieku, [w:] Życie lokalnych społeczności w Prusach Królewskich wpisane w księgi metrykalne, red. W. Zawadzki, Elbląg 2016, s. 59-74.

${ }^{24}$ Dziś wszystkie te miejscowości stanowią jedną wieś - Drewnicę.

25 Obecnie Drewnicę określa się jako położoną na Żuławach Wiślanych, jednakże w analizowanym okresie stanowiła ona część Mierzei, a dokładnie Starej Mierzei Wewnętrznej. 
Radosław Kubus, Wolfgang Naujocks

Tabela 1 (cd.)

\begin{tabular}{|c|c|c|}
\hline Rok & $\begin{array}{c}\text { Ogólna liczba } \\
\text { urodzeń }\end{array}$ & Bliźniaki \\
\hline 1822 & 93 & 1 \\
\hline 1823 & 91 & 6 \\
\hline 1824 & 78 & 2 \\
\hline 1825 & 95 & 1 \\
\hline 1826 & 87 & 1 \\
\hline 1827 & 75 & 0 \\
\hline 1828 & 76 & 0 \\
\hline 1829 & 75 & 3 \\
\hline 1830 & 55 & 0 \\
\hline 1831 & 61 & 0 \\
\hline 1832 & 40 & 1 \\
\hline 1833 & 70 & 0 \\
\hline 1834 & 58 & 0 \\
\hline 1835 & 72 & 5 \\
\hline 1836 & 60 & 1 \\
\hline 1837 & 69 & 4 \\
\hline 1838 & 68 & 3 \\
\hline 1839 & 69 & 2 \\
\hline 1840 & 68 & 2 \\
\hline 1841 & 74 & 1 \\
\hline 1842 & 76 & 1 \\
\hline 1843 & 74 & 0 \\
\hline 1844 & 66 & 0 \\
\hline 1845 & 98 & 1 \\
\hline 1846 & 85 & 1 \\
\hline 1847 & 86 & 1 \\
\hline 1848 & 91 & 1 \\
\hline
\end{tabular}


Bliźniaki zrośnięte i ciąże mnogie na Żuławach...

\begin{tabular}{|c|c|c|}
\hline Rok & $\begin{array}{c}\text { Ogólna liczba } \\
\text { urodzeń }\end{array}$ & Bliźniaki \\
\hline 1849 & 98 & 0 \\
\hline 1850 & 82 & 2 \\
\hline 1851 & 102 & 2 \\
\hline 1852 & 116 & 4 \\
\hline 1853 & 87 & 0 \\
\hline 1854 & 77 & 1 \\
\hline 1855 & 85 & 4 \\
\hline 1856 & 70 & 1 \\
\hline 1857 & 53 & 1 \\
\hline 1858 & 85 & 0 \\
\hline 1859 & 68 & 2 \\
\hline 1860 & 88 & 1 \\
\hline 1861 & 74 & 0 \\
\hline 1862 & 78 & 1 \\
\hline 1863 & 69 & 2 \\
\hline 1864 & 88 & 1 \\
\hline 1865 & 90 & 1 \\
\hline 1866 & 71 & 0 \\
\hline 1867 & 80 & 3 \\
\hline 1868 & 75 & 1 \\
\hline 1869 & 70 & 0 \\
\hline 1870 & 82 & 2 \\
\hline 1871 & 54 & 1 \\
\hline 1872 & 73 & 3 \\
\hline 1873 & 54 & 2 \\
\hline 1874 & 46 & 0 \\
\hline Summa & 4690 & $80(\sim 1,7 \%)$ \\
\hline
\end{tabular}

Źró dło: Archiwum Państwowe w Gdańsku 300,37/325-326; APG 1450/496/1-61 
O wyjątkowości narodzin trojaczków, czworaczków, czy też pięcioraczków świadczą również szersze statystyki obejmujące teren całej rejencji gdańskiej. I tak na przykład w 1835 roku w tej rejencji urodziło się 10306 dzieci z czego 130 bliźniaków i trojaczki²6. W roku 1838 odnotowano 13953 narodzin z czego 123 przypadki dotyczyły bliźniąt, a żaden - wieloraczków $^{27}$. Dla kolejnego roku było to 14413 narodzin, z czego 124 to bliźniaki oraz 2 porody, w wyniku których powiły się trojaczki ${ }^{28}$. Dla roku 1840 odnotowano 15648 urodzeń, w tym 153 bliźniaki i trojaczki ${ }^{29}$. Dla roku 1841 było to 16311 urodzeń, w tym 144 bliźniaki i 2 trojaczki ${ }^{30}$. W roku 1843 urodziło się 16770 dzieci w tym 183 bliźniaki i 1 trojaczki ${ }^{31}$. W 1844 roku zapisano 16960 narodzin w tym 188 bliźniaków i żadnych trojaczków ${ }^{32}$. W roku 1845 na 17346 urodzeń wskazuje się 141 bliźniaków i 2 trojaczków ${ }^{33}$. W 1846 roku odnotowano 17262 urodzeń w tym 179 bliźniaków i trojaczki ${ }^{34}$. Dla roku 1847 urodziło się 16051 dzieci w tym 162 bliźniaki i trojaczki ${ }^{35}$. Ustalenia te korespondują z uwagami Baszanowskiego. Pokazują, że ciąże w wyniku których zostały powite trojaczki, miały miejsce nawet rzadziej niż raz na 10 tysięcy urodzeń.

Choć niezwykle rzadko, to jednak odnotowuje się niekiedy na Żuławach ciąże mnogie kończące się narodzinami trojaczków, a nawet czworaczków. W 1634 roku na przykład we wzmiankowanej już miejscowości Neuteichwalde doszło do chrztu trojaczków ${ }^{36}$. W 1665 roku pastor w miejscowości Marynowy Johann Baumann ochrzcił czworaczki, tj. dziewczynkę Annę i trzech chłopców Jacoba, Johanna i Nicolasa ${ }^{37}$. Kilkanaście lat później, tj. w 1679 roku w miejscowości Gnojewo odbył się chrzest trojaczków, których ojcem był miejscowy zagrodnik ${ }^{38}$. Pochodzącemu z okolic Nowego Dworu Gdańskiego menonicie, w roku 1699, urodziły się trojaczki ${ }^{39}$. Kilka

${ }^{26}$ Amtsblatt der Königlichen Regierung zu Danzig [dalej cyt. AzD] 1836, s. 172-175.

27 AzD 1839, s. 127-129.

${ }^{28}$ AzD 1840, s. 95-96.

${ }^{29}$ AzD 1841, s. 104-106.

${ }^{30}$ AzD 1842, s. 48-50.

31 AzD 1844, s. 69.

32 AzD 1845, s. 95-97.

${ }^{33}$ AzD 1847, s. 93-95.

${ }^{34}$ AzD 1847, s. 73-75.

35 AzD 1848, s. 137-139.

${ }^{36}$ Zedlers Universal-Lexicon, Bd. 55, Leipzig-Halle, s. 306. Jest to dokładny odpis od A. Hartwicha - por. A. Hartwichs, Geographisch-historische Landesbeschreibung deren dreyen im Polnischen Preußen liegenden Werdern als des Danziger-Elbing-und Marienburgischen..., Königsberg 1722, s. 46.

37 Tamże.

38 Tamże.

39 Tamże. 
lat później, tj. w 1705 roku nauczycielka (Schulmeisterin) we wsi Marynowy również powiła trojaczki. W czasie szalejącej na terenie Prus Królewskich epidemii dżumy w roku 1709 w miejscowości Lipinka, pewna kobieta także powiła troje dzieci, które choć ochrzczone, nie przeżyły zbyt długo ${ }^{40}$.

O ile narodziny bliźniaków notuje się od czasu do czasu w materiale źródłowym, to narodziny trojaczków były wówczas swego rodzaju doniosłym i wyjątkowym wydarzeniem. Bardzo rzadkim i niezmiernie osobliwym były natomiast narodziny czworaczków. Narodziny pięcioraczków w czasach nowożytnych stawały się ewenementem. Analiza wielu ksiąg metrykalnych parafii ewangelickich z terenu Żuław pozwoliła odnaleźć w zasadzie jeden przykład tego typu narodzin. Ów przypadek miał miejsce w roku 1780 w miejscowości Lubieszewo. Otóż związek małżeński Marii Doercks, córki zmarłego w miejscowości Bronowo Albinusa Lietza oraz jej męża nowodworskiego tkacza Davida Doercks został zawarty 9 lipca 1778 roku. 31 maja 1780 roku Maria w wielkich bólach powiła bliźniaki, Davida i jego martwo urodzoną siostrę. Bóle jednak nie ustawały, okazało się bowiem że w łonie matki znajdowały się jeszcze trzy kolejne, martwe już noworodki. W ciągu czterech dni powiła zatem Maria pięcioraczki, z których jedynie jedno dziecko przeżyło 8 dni (od 1 do 8 czerwca) i zostało ochrzczone imieniem David. Wkrótce po śmierci syna, 9 czerwca zmarła matka. Przyczyną zgonu były powikłania poporodowe (in einem sehr harten Wochenbette) ${ }^{41}$.

Wydaje się, że odnaleziony poród pięcioraczków należy do wydarzeń wyjątkowych nie tylko w skali Żuław, ale i terenów całej Rzeczpospolitej. Próżno szukać analogicznej informacji dla wskazanego okresu. W dodatku takiej informacji, w której mielibyśmy do czynienia z tym, że jedno z dzieci żyło jeszcze przez okres 8 dni. Zazwyczaj bowiem dzieci takie umierały w przeciągu pół godziny od chwili narodzin, o czym świadczy przykład pięcioraczków urodzonych w Neapolu w 1838 roku² $^{42}$.

Analizując wskazany przypadek pięcioraczków z miejscowości Lubieszewo, należy stwierdzić, że $\mathrm{w}$ momencie połogu ciąża musiała być już $\mathrm{w}$ dość zaawansowanym stanie. $\mathrm{Z}$ dużym prawdopodobieństwem można również przyjąć, że przy porodzie nie asystował żaden lekarz, skoro najpierw poinformowano o narodzinach bliźniaków, a dopiero w późniejszym okresie zorientowano się, że kobieta nosi w łonie jeszcze troje pozostałych dzieci. Zastanawiające wydaje się również, jak to możliwe, że poród trwał aż cztery dni. Kiedy zaczęły się bóle porodowe i jak silne musiały być? Wprost niewyobrażalne wydaje się nam z dzisiejszej perspektywy cierpienie, jakie

\footnotetext{
40 Tamże.

${ }^{41}$ Evangelische Zentralarchiv in Berlin 1780, s. 524.

42 „Neuemedicinisch-chirurgische Zeitung” 1840, nr 51, s. 432.
} 
musiała znieść owa kobieta, nie tylko do momentu poczęcia wszystkich pięciorga dzieci, ale zapewne aż do śmierci, która nastąpiła w przeciągu 9 dni od chwili rozpoczęcia porodu.

Ponad 240 lat upłynęło od narodzin lubieszewskich pięcioraczków, nim opinia publiczna usłyszała po raz kolejny o - tym razem głośnych - narodzinach pięcioraczków, które przyszły na świat 12 maja 1971 roku w Gdańsku. W tym przypadku finał był jednak zupełnie inny. Wszystkie pięcioraczki żyją po dziś dzień. Poród pięcioraczków gdańskich przedstawiano na pierwszych stronach gazet (zapewne jako triumf socjalistycznej technologii). Między innymi pisano o tym na łamach Dziennika Bałtyckiego", gdzie przy tej okazji nie omieszkano przypomnieć o mających kilka lat wcześniej narodzinach czworaczków w miejscowości Trutnowy na Żuławach Gdańskich. Pisano bowiem:

Na marginesie [...] warto przypomnieć, że przed kilkoma laty sensacje w powiecie gdańskim wywołało urodzenie czworaczków w rodzinie Miazgowiczów we wsi Trutnowy w powiecie gdańskim. Czwórka - Ryszard, Bożena, Hania i Jola Miazgowiczowie chodzą do szkoły w Trutnowach i uczą się dobrze ${ }^{43}$.

To ostatnie stwierdzenie może sugerować, iż sądzono wówczas, że wieloraczki mogą posiadać obniżone zdolności poznawcze, a być może nawet deficyty intelektualne.

Skoro sensacją było urodzenie czworaczków w Trutnowych w latach 60. XX wieku, a później słynne narodziny gdańskich pięcioraczków, to cóż dopiero myśleć o przypadku z Lubieszewa? Księgi metrykalne niezwykle rzadko odnotowują przypadki ciąż mnogich, tym bardziej zatem na uwagę zasługuje przypadek z Lubieszewa. Z pewnością wydarzenie należało do wyjątkowych, ale czy jedynych wydarzeń tego typu w okresie XVIII wieku? Bez dokładniejszych badań nad księgami metrykalnymi ewangelickich oraz katolickich parafii z terenu Prus Królewskich nie sposób odpowiedzieć na tak postawione pytanie.

Podsumowując, wypada stwierdzić, że tylko szeroka współpraca badaczy zajmujących się demografią historyczną może w przyszłości dać odpowiedź na pytanie o skalę zjawiska, jakim były nietypowe przypadki narodzin nie tylko na terenie Żuław, czy Pomorza, ale i rówinież czałej Rzczpospolitej. Aby zrealizować przedstawiony postulat badawczy potrzeba jednak drobiazgowej kwerendy w obficie zachowanym materiale źródłowym, jaki w tym

${ }^{43}$ Gdańskie pięcioraczki $w$ dalszym ciagu w centrum zainteresowania społeczeństwa, „Dziennik Bałtycki” 1971, nr 119. 
przypadku w pierwszej kolejności stanowią księgi metrykalne. Być może wówczas uda się odpowiedzieć również na pytanie o wyjątkowość przytaczanych przez nas w artykule przykładów. Czy rzeczywiście narodziny żuławskich pięcioraczków z roku 1780 stanowią wydarzenie unikalne w skali Pomorza, a nawet Rzeczpospolitej, czy też tego typu przypadki zdarzały się częściej? Jak wysoka była śmiertelność w przypadku narodzin wieloraczków? Czy przy tego typu porodach asystowali lekarze bądź wykwalifikowane akuszerki? W końcu jak społeczeństwo (szczególnie na wsi) odbierało tego typu przypadki? Precyzyjna odpowiedź na te i wiele podobnych pytań wymaga pogłębionych studiów interdyscyplinarnych, które jak mają nadzieję autorzy tegoż przyczynku, zostaną w przyszłości zmaterializowane w postaci konkretnych projektów badawczych.

\section{BIBLIOGRAFIA}

\section{Źródła archiwalne}

Archiwum Państwowe w Gdańsku 300,37/325-326; APG 1450/496/1-61.

Evangelische Zentralarchiv in Berlin 6647, Ladekopp, Kreis Marienburg/Westpreussen. Bestattungen 1779-1824.

\section{Źródła drukowane}

Amtsblatt der Königlichen Regierung zu Danzig, 1836-1848.

Gdańskie pięcioraczki $w$ dalszym ciagu $w$ centrum zainteresowania społeczeństwa, „Dziennik Bałtycki" z 20 maja 1971, nr 119 (8348).

Hartwichs A., Geographisch-historische Landesbeschreibung deren dreyen im Polnischen Preußen liegendenWerdern als des Danziger-Elbing-und Marienburgischen ..., Königsberg 1722.

Königlich genehmigte West-Preußische Elbingsche Zeitung von Staats- und gelehrten Sachen, 1811.

Neue medicinisch-chirurgische Zeitung, 1840, Nr 51.

Ruysch F., Frederici Ruyschii, anatomiae et botanices professoris thesaurus anatomicus primus [-decimus] cum figurisaeneis = Het eerste [-zynde] anatomisch Cabinet van Frederic Ruysch, professor van de Anatomiae en Botan met kopere Platen, Amsterdam 1701-1716.

Siek B., Szarszewski A., Vita medicorum Gedanensium Ludwika von Hammenai Valentina Schiieffa, Gdańsk 2015.

Zedlers Universal-Lexicon, Bd. 55, Leipzig-Halle 1732-1754. 


\section{Opracowania}

Baszanowski J., Przemiany demograficzne w Gdańsku w latach 1601-1846, Gdańsk 1995.

Bogucka M., Health care and poor relief in Danzig (Gdansk). The sixteenth- and first half of the seventeenth century, [w:] Health Care and Poor Relief in Protestant Europe 1500-1700, ed. O.P. Grell and A. Cunningham, London 1997, s. 204-219.

Bogucka M., Illness and Death in a Maritime City. Gdańsk in the Seventeenth Century, [w:] Człowiek i świat. Studia z dziejów kultury i mentalności XV-XVIII w., Warszawa 2008, s. 394-410.

Fabiani B., Niziołki, łokietki, karlikowie, Warszawa 1980.

Iżycka-Świeszewska E., Hermann B., Gulczyński J., Johann Adam Kulmus i publiczna sekcja zwłok bliźniąt zrośniętych w 1724 roku, [w:] Joachim Oelhaf i jego następcy, red. A. Szarszewski, B. Siek, Gdańsk 2013, s. 83-91.

Kaufmann J., Über Danziga Sanitats - und Medizinalwesenim 16. und 17. Jhr., „Mitteilungen des Westpreussischen Gesichtsverein" 4 (1904) H. 1-2, s. 4-17, 26-36.

Kämpfert J.H., Aspekte der Medizingeschichte in Danzig im Rahmen der Naturforschenden Gesellschaft, [w:] Deutsch-polnische Begegnung zu Wissenschaft und Kultur Schriftenreihe der Danziger Naturforschenden Gesellschaft, Bd. 2, hrsg. Gornig H. Gilbert, Lübeck 1998, s. $36-46$.

Kämpfert J.H., Danziger Naturwissenschaftler. Ein Überblick vom ausgehenden Mittelalter bis zum 19. Jahrhundert, [w:] Danzig in acht Jahrhunderten. Beiträge zur Geschichte eines hansischen und preußischen Mittelpunktes. Quellen und Darstellungen zur Geschichte Westpreußen, Bd. 23, hrsg. von Bernhart Jähnig, Peter Letkemann, Münster 1985, s. 185-212.

Kizik E., Uwagi o ruchu naturalnym $w$ parafii NMP $w$ Gdańsku $w$ drugiej połowie XVII i $w$ XVIII wieku, [w:] Życie lokalnych społeczności w Prusach Królewskich wpisane w księgi metrykalne, red. W. Zawadzki, Elbląg 2016, s. 59-74.

Konieczna S., Sekcja zwłok z 1613 r. noworodka z Pruszcza Gdańskiego z punktu widzenia neurologa, [w:] Joachim Oelhaf i jego następcy, red. A. Szarszewski, B. Siek, Gdańsk 2013, s. 43-49.

Kooijmans L., Niebezpieczna wiedza. Wizie i lęki w czasach Jana Swammerdama, tłum. R. Pucek, Warszawa 2010.

Kucharski A., „Theatrumperegrinandi”. Poznawcze aspekty staropolskich podróży w epoce późnego baroku, Toruń 2013.

Malewicz M.H., Zjawiska przyrodnicze w relacjach dziejopisarzy polskiego średniowiecza, Wrocław 1980.

Mathew R.P., Francis S., Basti R.S., Suresh H.B., Rajarathnam A., Cunha P.D., Rao S.V., Bliźnięta nierozdzielone - rola badań obrazowych oraz nowe technologie, b.m.w. 2017.

Mokrzecki L., Trzy wieki nauki gdańskiej. Szkice z dziejów od XVI do XVIII wieku, Wrocław 1976.

Paluchowski J., Danziger Erfahrungen w latach 1739-1793. Studium z dziejów gdańskiego czasopiśmiennictwa, Warszawa 2013.

Pomian K., Zbieracze i osobliwości. Paryż - Wenecja XVI-XVIII wiek, tłum. A. Pieńkos, Lublin 2001.

Schwarz F., Ärzte im 16.-18. Jahrhundert, „Danziger Familiengesichtliche Beiträge” 1939, H. 4, s. 27-36.

Schwarz F., Ärzte im 16.-18. Jahrhundert, „Danziger Familiengesichtliche Beiträge” 1941, H. 6, s. 13-22. 
Serczyk J., Albertyna. Uniwersytet w Królewcu (1544-1945), Olsztyn 1994.

Sokół S., Eustachy Holwell leczył jednorożcem, (Kartka z dziejów gdańskiej medycyny XVII w.), „Rocznik Gdański” 1955, t. XIV, s. 180-188.

Sokół S., Historia gdańskiego cechu chirurgów 1454-1820, Wrocław-Warszawa 1957.

Sokół S., Medycyna w Gdańsku w dobie odrodzenia, Wrocław-Warszawa 1960.

Szarszewski A., Joachim Oelhaf (1570-1630), [w:] Joachim Oelhaf i jego następcy, red. A. Szarszewski, B. Siek, Gdańsk 2013, s. 32-35.

Wieczorkiewicz A., Monstruarium, Gdańsk 2019.

Wijaczka J., Procesy o czary w Prusach Ksiq̨żęcych (Brandenburskich) w XVI-XVIII wieku, Olsztyn 2019.

Radosław Kubus, Wolfgang Naujocks

\section{CONJOINED TWINS AND MULTIPLE PREGNANCY IN ŻUŁAWY A CONTRIBUTION TO RESEARCH ON THE HISTORY OF TOCOLOGY}

onjoined twins and multiple pregnancies are a topic that has not yet been elaborated. This text is only a small contribution, where on the basis of record books, reference books and the press, attempts are made to find cases of unusual birth. Certainly the data cited in the text are incomplete and need to be supplemented with further sources. The case of the birth of five children in the village of Lubieszewo, recorded in the record books for 1780, seems quite unique. Is this the first case of quintuplets in Poland to date? Without more detailed research on it, we will not know the answer to this question.

Keywords: Zulawy, demography, tocology, child, family, record books. 